\title{
Sphecid Wasp`s Diversity and Distribution Study of Bengaluru, Karnataka
}

\author{
Soumya Patil" and D. Jemla Naik \\ Department of Agricultural Entomology, College of Agriculture, \\ UAS, GKVK, Bengaluru -560 065, India \\ *Corresponding author
}

A B S T R A C T

\section{Keywords}

Sphecid, Diversity, Distribution, Abundance

Article Info

Accepted:

10 July 2020

Available Online:

10 August 2020
A total of 534 specimens of apoid wasps, representing 65 species were collected from Bengaluru. The wasps were identified to their respective subfamilies, generic and species levels. In general, species occurrence and their abundance were higher in dry zones and transitional zones and less in eastern transition zone. The most abundant genera were Chalybion, Sceliphron and Ammophila during 2017 and along with these Carinostigmus and Pison were abundant during 2018 in Bengaluru.

\section{Introduction}

Biodiversity is important for the sustenance of harmonious life on earth. The composition and richness of species assemblages also strongly influences ecosystem functioning and stability (Naeem et al., 1994; Tilman and Downing 1994; McCann 2000). Insects have very distinct life histories and, the time of sampling can have a dramatic impact on the assessment of diversity depending on the group chosen to study. The most frequently used diversity index is the number of species, i.e. the diversity of species, although it may be applied to any taxonomic stage such as genus, family, order, etc. (Magurran, 1988).
Sphecid wasps have distinctive nesting behaviour. It is strongly related to the behaviour of prey hunting. Their nests can be categorized arbitrarily into two groups depending on the place of nesting: 1) subterranean nests and 2) above-ground nests. The latter involves twig nesting, cavity nesting, and the familiar mud daubers. Although the details of nest construction behaviour differ greatly between species, patterns are generally consistent and relatively fixed between species within a genus (Bohart and Menke, 1976). Not all sphecids build nests in an original burrow. The twig nesters, for example, usually take over the bees' barren tunnels. Likewise, many will be remodelling the nest by other daubers of mud. 
The genera such as Larra and some Chlorion use the burrow built by their victim (Bohart and Menke, 1976).

As mentioned by Gayubo et al., (2005) the complexity of sphecids, together with the lower genetic diversity that characterizes Hymenoptera with respect to other orders (Unruh and Messing 1993), make them particularly sensitive to certain forms of environmental damage, although they are able to exist in small isolated populations (Day 1991). This is why the Hymenoptera are particularly important biological indicators, apart from the intrinsic interest of their complex models of behaviour. Furthermore, many species profit from zones of ecotone in ecological successions and zones in which, owing to the natural conditions or human interference, there are areas appropriate for nesting (Duelli et al., 1990; Shlyakhtenok 2000; Kirby 2001). Certain species coexist very well with humans, human agricultural practices and techniques, and in built-up areas, and indeed their absence can be seen as an indicator of the poverty of a given environment (Day 1991; Kirby 2001). In this sense, the Spheciformes form a group that can be used to delimit potential areas of protection, in which not only such "natural" (well-conserved) zones should be included but also other surrounding areas, thereby making biodiversity conservation compatible with the continuance of traditional customs.

Studies on sphecid wasps [Sphecidae (sensu lato)] from India are poor and there have been no revisionary works on the Indian fauna except for a few genera and species. The last comprehensive work on this group was by Bingham, which dates back to late 1890s who recorded 168 species of Sphecid wasps as occurring in the Indian sub-continent. Cameron (1888) and Turner (1912) have published on the Indian sphecid fauna. Ramakrishna (1920) recorded a species of sphecid wasp, Philanthus ramakrishnae, as an enemy of Apis indica from Bababuddin hills in the Western Ghats of Karnataka. Usman and Puttarudraiah (1955) recorded 25 species of Sphecid wasps in 14 genera from Mysore state of which Bingham recorded seven species earlier from Bangalore. Krombein published a series of monographs on the biosystematics of wasps of Ceylon, which included several families of Spheciformis (Krombein, 1979; 1982; 1984a, 1984b; 1985; 1994).

Later, Cameron (1889) and Turner (1912) also published on the Indian sphecid fauna. Bohart and Menke (1976) published generic revision on the world fauna. The recent works on Indian sphecidae is by Gupta (1995); Jonathan et al., (2000) and Kundu et al., (2006). In Kerala 47 species of sphecid wasps has been listed [Sudheendrakumar et al., 1989; Suresh et al.,1999, Madhavikutty,2004; Aswathy, 2012].

\section{Materials and Methods}

Studies on the taxonomy of superfamily Apoidea were conducted from 2016 to 2019 at the Department of Agricultural Entomology, University of Agricultural Sciences, Bangalore. A total of 2500 specimens were examined during the study. Below are the detailed study methods followed during the course of research.

Apoid wasps were captured from all the ten agro-climate zones of Karnataka and different parts of Bengaluru (Fig 1 and 2). Insect sweep net, malaise trap, bee bowls, yellow pan trap and trap nests were used for collections. Random walks were made for collection on each sampling day in cultivated and uncultivated areas. Soon after sampling, the samples were transferred to tubes containing 70-90 per cent alcohol and labelled with the date of collection and location, and brought to 
the laboratory for further studies. Wasps were also collected using bee bowls of different colours (yellow, white and blue). Bee bowls were maintained in fields and horticultural gardens for 24 hours with 2 per cent soap water. Wasps drowned in each bowl were strained in the field and extracted and stored in separate alcohol tubes and labelled. The label included the colour of the bee bowl, date of collection and location.

The sphecoid wasp's diversity was estimated using sampling data of Bengaluru during the years 2017 and 2018. Sampling was carried out at thrice in a week in different ecosystems. Sampling was made by using bee bowls, malaise trap, trap nests and sweep nets. In Bengaluru, collections were made using traps and bee bowls ( 5 traps and 5 bee bowls) placed on the ground surface spaced at a distance of $5 \mathrm{~m}$. The traps were placed in the morning around $08.00 \mathrm{hrs}$. and were collected back around $17.00 \mathrm{hrs}$. Insects from each trap were collected by filtering the water using a nylon filter and all hymenopterans were separated and transferred to a butter paper packet with pertinent labels giving details of the date of sampling, location, and sample number. Sweep net samples were also collected between 10.00 and $15.00 \mathrm{hrs}$. on the same days. The specimens were processed, pinned and labelled for further analysis. Observations were made on the number of species and the number of individuals in each species from each sample and the same data was used to compute diversity indices.

\section{Data Analysis}

The specimen label data were used for computing species richness, evenness and diversity indices for comparison across locations.

Species richness: It represents the number of different species distributed in each zone. It was calculated using Margalef's diversity index.

Margalef's diversity index

$\operatorname{Dmg}=(\mathrm{S}-1) / \ln \mathrm{N}$

Where $\mathrm{S}$ is the number of species recorded and $\mathrm{N}$ is the total number of individuals combined of all species

\section{Diversity indices}

1. Shannon-Weiner diversity index ( $\left.\mathrm{H}^{\prime}\right)$

The Shannon-Weiner diversity index was calculated by the following equation:

$\mathrm{H}^{\prime}=-\Sigma$ piln pi

2. Simpson Index (D)

$\mathrm{D}=1-\Sigma p i^{2}$

Where pi is the proportion of individuals of the $i^{\text {th }}$ species found

Evenness: It is a measure of the relative abundance of each species in a habitat. If each species is equally abundant, evenness is one. Evenness was calculated using the following formula:

$\mathrm{E}=\mathrm{H}^{\prime} / \ln \mathrm{S}$

Where $\mathrm{H}^{\prime}$ is the Shannon index and $\mathrm{S}$ is the total number of species present. Zone-wise estimates for species richness (Margalef's index, $\mathrm{D}_{\mathrm{mg}}$ ), evenness and local diversity (Shannon's, (H') and Simpson's (D) indices) were calculated using pooled data. Further, Shannon's indices for various zones were tested for differences using Student's t-test. Moristia-Horn dissimilarity index was adopted for comparisons across locations (Magurran, 1983). 


\section{Results and Discussion}

These wasps are associated with mankind in the field of agriculture and general ecology, acting as predators, pollinators, parasites and parasitoids. They are valuable bio- indicators and biocontrol agents and hence knowing their diversity is important.

Though most species of Spheciformes have been collected and described from Central and Northern parts of India, the sphecoid fauna of the country is still imperfectly known. Fabricius (1775) and Bingham (1897) recorded 168 species from the Indian subcontinent.

The present study aims to add valuable information about the diversity and distribution of apoid wasps from Bengaluru during the years 2017 and 2018. The results in detail are discussed below.

\section{Diversity of Apoid wasps of Bengaluru for} the years 2017 and 2018

As it is known that diversity can vary with climate, this study was taken up with an objective to document the diversity of apoid wasps in ten agro climatic zones of Karnataka and also the diversity of apoid wasps in Bengaluru. A total of 534 specimens of apoid wasps, representing 65 species were collected. The wasps were identified to their respective subfamilies, generic and species levels.

A few earlier studies have attempted to prepare faunal lists of apoid wasps of various regions of Karnataka i.e in Dharwad and Bengaluru. Hiremath and Ganesh (2016) conducted study on hymenopteran diversity of UAS, Dharwad and reported 28 species from 30 genera in which they listed 4 species of sphecid wasps. Geetha (2010) conducted studies in Bengaluru region and reported 38 species belonging to 21 genera. The present study attempted to know the species diversity and their abundance of Bengaluru.

Using the collection data of Bengaluru during 2017 and 2018 of Apoid wasps across the months, the study tried to estimate diversity indices and their abundance. Month-wise estimates for species richness (Margalef's index, $\mathrm{D}_{\mathrm{mg}}$ ), evenness and local diversity, Shannon's, (H') and Simpson's indices (D) were computed using the sampling data.

The results for the year 2017 were as follows, the highest number of species (S) were collected during the month of November followed by July and individuals $(\mathrm{N})$ during October followed by November (Table 1).

It was lowest in June followed by January and May. Simpson and Shannon index revealed similar trends, diversity was highest during July $\left(\mathrm{D}=0.909 ; \quad \mathrm{H}^{`}=2.398\right)$ followed by November $\quad(\mathrm{D}=0.849 ; \quad \mathrm{H}=2.219) \quad$ and September $\quad(\mathrm{D}=0.776 ; \mathrm{H}=1.681)$. It was lowest during June $\left(\mathrm{D}=0 ; \mathrm{H}^{`}=0\right)$ followed by May $\left(\mathrm{D}=0.444 ; \quad \mathrm{H}^{`}=0.636\right)$ and March $(\mathrm{D}=0.480 ; \mathrm{H}=0.673)$. Margalef Index was highest in July $\left(\mathrm{D}_{\mathrm{mg}}=4.17\right)$ and lowest during June $\left(D_{\mathrm{mg}}=0\right)$.

During the year 2018, the results were quite evenly distributed. Abundance was variable and richness was evenly distributed across the months, with little differences.

The abundance $(\mathrm{N})$ and richness(S) was highest in the following months February, March and July, March, June and October respectively (Table 2). Simpson and Shannon indices were the highest and the lowest in the following months [March $(\mathrm{D}=0.823$; $\left.\mathrm{H}^{`}=1.891\right)$, June $\left(\mathrm{D}=0.816 ; \mathrm{H}^{`}=1.810\right)$ and February $\quad\left(\mathrm{D}=0.816 ; \mathrm{H}^{`}=1.742\right)$; $\quad$ May $\left(\mathrm{D}=0 ; \mathrm{H}^{`}=0\right)$, December $\left(\mathrm{D}=0.500 ; \mathrm{H}^{`}=0.867\right)$ and August $\left(\mathrm{D}=0.531 ; \mathrm{H}^{`}=0.900\right)$ respectively. 
Table.1 Summary of diversity and abundance measures computed to estimate the diversity of apoid wasps across the months during the year 2017, Bengaluru

\begin{tabular}{|c|c|c|c|c|c|c|c|c|c|c|c|c|}
\hline & Jan & Feb & Mar & Apr & May & June & July & Aug & Sept & Oct & Nov & Dec \\
\hline Richness (S) & 2 & 3 & 2 & 4 & 2 & 1 & 11 & 4 & 7 & 6 & 13 & 6 \\
\hline Abundance (N) & 2 & 4 & 5 & 5 & 3 & 1 & 11 & 4 & 22 & 38 & 29 & 15 \\
\hline Dominance (D) & 0.500 & 0.375 & 0.520 & 0.28 & 0.555 & 1 & 0.090 & 0.250 & 0.223 & 0.374 & 0.151 & 0.288 \\
\hline Simpson 1ndex (D) & 0.500 & 0.625 & 0.480 & 0.72 & 0.444 & 0 & 0.909 & 0.750 & 0.776 & 0.626 & 0.849 & 0.711 \\
\hline Shannon Index (H') & 0.693 & 1.040 & 0.673 & 1.332 & 0.636 & 0 & 2.398 & 1.386 & 1.681 & 1.221 & 2.219 & 1.455 \\
\hline Evenness (E) & 1 & 0.942 & 0.980 & 0.947 & 0.944 & 1 & 1 & 1 & 0.767 & 0.565 & 0.707 & 0.714 \\
\hline Margalef Index (D mg) & 1.443 & 1.443 & 0.621 & 1.864 & 0.910 & 0 & 4.17 & 2.164 & 1.941 & 1.375 & 3.564 & 1.846 \\
\hline
\end{tabular}

Table.2 Summary of diversity and abundance measures computed to estimate the diversity of apoid wasps across the months during the year 2018, Bengaluru

\begin{tabular}{|c|c|c|c|c|c|c|c|c|c|c|c|c|}
\hline & Jan & Feb & Mar & Apr & May & June & July & Aug & Sept & Oct & Nov & Dec \\
\hline Richness (S) & 5 & 6 & 8 & 5 & 1 & 7 & 4 & 3 & 3 & 7 & 4 & 3 \\
\hline Abundance (N) & 8 & 17 & 17 & 6 & 12 & 14 & 16 & 8 & 5 & 11 & 9 & 6 \\
\hline Dominance (D) & 0.218 & 0.183 & 0.176 & 0.222 & 1 & 0.183 & 0.445 & 0.468 & 0.360 & 0.256 & 0.284 & 0.500 \\
\hline Simpson 1ndex (D) & 0.781 & 0.816 & 0.823 & 0.777 & 0 & 0.816 & 0.554 & 0.531 & 0.640 & 0.743 & 0.716 & 0.500 \\
\hline Shannon Index (H) & 1.560 & 1.742 & 1.891 & 1.561 & 0 & 1.810 & 1.041 & 0.900 & 1.055 & 1.666 & 1.311 & 0.867 \\
\hline Evenness (E) & 0.951 & 0.951 & 0.827 & 0.952 & 1 & 0.872 & 0.707 & 0.820 & 0.957 & 0.756 & 0.927 & 0.793 \\
\hline Margalef Index (Dmg) & 1.924 & 1.765 & 2.471 & 2.232 & 0 & 2.274 & 1.082 & 0.961 & 1.243 & 2.502 & 1.365 & 1.116 \\
\hline
\end{tabular}


Fig.1 Locations selected for collection of Apoid wasps from Karnataka

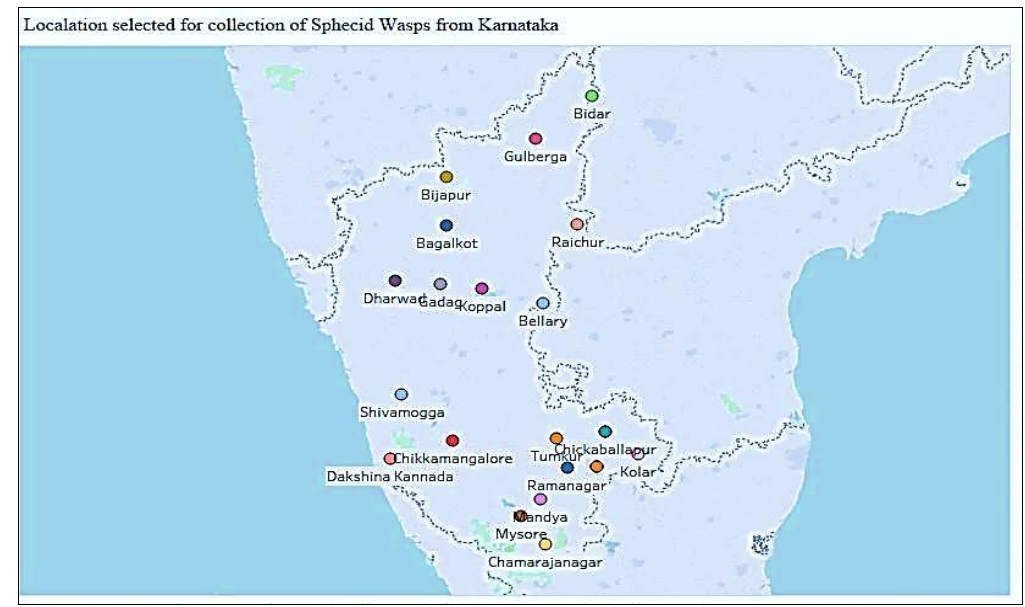

Fig.2 Map of Bengaluru for Apoid wasps collection

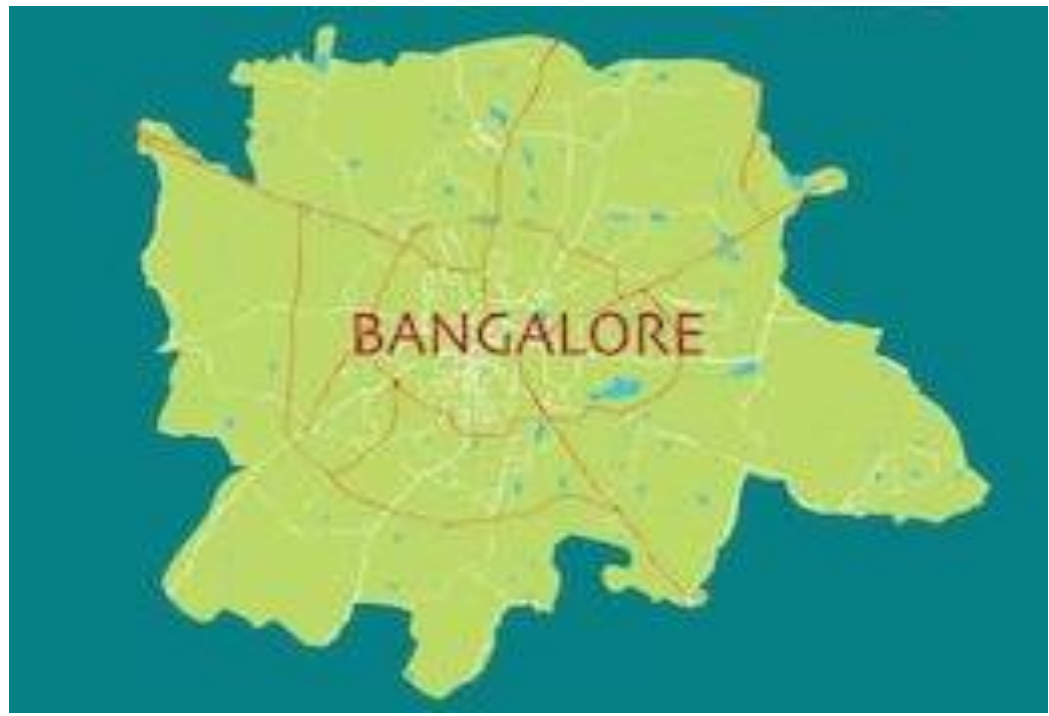

In the present study, a significant positive correlation was found between abundance of apoid wasps with rainfall and relative humidity and a negative correlation with temperature during 2017 and it was contrasting during 2018 where abundance was positively correlated with temperature and negatively correlated with rainfall and relative humidity. Variation in diversity and richness appeared to be related to environmental factors including the availability and abundance of host upon which they prey. In fact, Ebeling et al., (2011) suggested that species richness is positively correlated with the density and diversity of links within species interaction webs that can stabilize ecosystem services. The most abundant genera were Chalybion, Sceliphron and Ammophila during 2017 and along with these Carinostigmus and Pison were abundant during 2018.

\section{Acknowledgements}

The author thanks University of Agricultural Sciences, Bengaluru, NFST and ICAR for 
financing and facilitating this study. The support from advisor and classmates are acknowledged.

\section{References}

Aswathy T.V., 2012, Sphecid wasp fauna in southern Western Ghats of Kerala. M.Sc. Thesis, Submitted to University of Agricultural Sciences, Bangalore.

Bingham, C. T., 1897, The fauna of British India. Hymenoptera vol. I, Taylor and Francis, London., 579pp.

Bohart, R. M. and Menke, A. S., 1976, Sphecid Wasps of the World: A Generic Revision. University of California Press, 695pp.

Cameron, P., 1888, Descriptions of twentythree new species of Hymenoptera. Memoirs and Proceedings of the Manchester Literary \& Philosophical Society, 1(4): 159-183.

Cameron, P., 1889. Hymenoptera Orientalis [sic]; or contributions to a knowledge of the Hymenoptera of the Oriental Zoological Region. Memoirs and Proceedings of the Manchester Literary and Philosophical Society, 2(4): 91-152.

Day, M. C., 1991, Towards the conservation of aculeate Hymenoptera in Europe. Strasbourg: Council of Europe. 80 p. (Nature and Environment Series; 51).

Duelli, P., Studer, M., Marchand, I. and Jakob, S., 1990, Population movements of arthropods between natural and cultivated areas. Biological Conservation 54:193-207.

Ebeling, A., Klein, A. and Tscharntke, T., 2011, Plant-flower visitor interaction webs: temporal stability and pollinator specialization increases along an experimental plant diversity gradient. Appl. Ecol., 12: 300-309.

Fabricius, J. C. H., 1775, The system of Entomologiae, sistens Insectorum classes, ordines, genera, species, adiectis synonymis, places, and the descriptions of, those glittering observances, Kortii,
Flensburgi et Lipsiae, 1-832 pp.

Gayubo, S. F., Gonzalez, J. A., Asis, J. D. and Tormos, J., 2005, Conservation of European environments: the Spheciformes wasps as biodiversity indicators (Hymenoptera: Apoidea: Ampulicidae, Sphecidae and Crabronidae). J. Natural History, 39: 2705-2714.

Geeta, N., 2010, Studies on Sphecid wasp of Bangalore (Apoidea: Spheciformes). M.Sc. Thesis. Submitted to University of Agricultural Sciences, Bangalore.

Geeta, N., 2010, Studies on Sphecid wasp of Bangalore (Apoidea: Spheciformes). M.Sc. Thesis. Submitted to University of Agricultural Sciences, Bangalore.

Gupta, S. K., 1995, Hymenoptera, in Zoological Survey of India. Himalaya Ecosystem Series, Part 1, Uttar Pradesh, 81-89 pp.

Hiremath, R. and Ganesh, C. B., 2016, A preliminary study on Hymenopteran diversity in university of agricultural sciences campus, Dharwad. J. Entomol. Zoo. Stud., 4(4): 1271-1274.

Jonathan, J. K., Ray, K. K. and Kundu, B.G., 2000, Insecta: Hymenoptera: Sphecidae. State Fauna Series 4; Fauna of Meghalaya. Part 7; Insecta. Zoological Survey of India, Calcutta. 1-628 pp.

Kirby, P., 2001, Habitat management for invertebrates: a practical handbook. Sandy, Bedfordshire: National Power, JNCC and RSPB. 150 p.

Krombein, K. V., 1979, Biosystematic studies of Ceyloneses wasps, V: a monograph of the Ampulicidae (Hymenoptera: Sphecoidea). Smithsonian Contributions to Zoology, 298:1-29.

Krombein, K. V., 1984a, Biosystematic studies of Ceylonese wasps, XIII: a monograph of the Stizinae (Hymenoptera: Sphecoidea, Nyssonidae). Smithsonian Contributions to Zoology, 388: 1-37.

Krombein, K. V., 1984b, Biosystematic studies of Ceylonese wasps, XIV: a revision of Carinostigmus Tsuneki (Hymenoptera: Sphecoidea: Pemphredonidae). Smithsonian Contributions to Zoology, 
396: 1-37.

Krombein, K. V., 1985, Biosystematic studies of Ceylonese wasps, XV: a monograph of the Alyssoninae, Nyssoninae, and Gorytinae (Hymenoptera: Sphecoidea: Nyssonidae). Smithsonian Contributions to Zoology, 414: 1-42.

Krombein, K. V.1982, A preliminary analysis of affinities and derivation of the wasp fauna of Sri Lanka (Hymenoptera: Aculeata). Entomologia Generalis, 8: 4350.

Kundu, B. G., Ghosh, S. N. and Tiwary, R, 2006, Insecta: Hymenoptera: Aculeata: Sphecidae. Zool. Surv. India, Fauna of Arunachal Pradesh, State Fauna Series, 13(2): 399-426.

Madhavikutty, M., 2004, Description of a new species of the genus Trirogma Westwood (Hymenoptera: Spheciformes) from India, 593-596 pp.

Magurran, A. E. 1988. Ecological diversity and its measurements. Croom Helm, Ryde, Australia.

Mccann K S. 2000. The diversity-stability debate. Nature, 405(6783): 228233.Magurran, 1988

Naeem S, L J Thompson, S P Lawler, 1994. Declining biodiversity can alter the performance of ecosystems. Nature, 368(6473): 734-737.

Ramakrishna, A.T., 1920, Some insects recently noted as injurious in South India.Rep. Proc. Third Ent. Meet. Pusa, 1: 314-326.

Ramakrishna, A.T., 1920, Some insects recently noted as injurious in South India. Rep.
Proc. Third Ent. Meet. Pusa, 1: 314-326.

Shlyakhtenok, A. S., 2000, Effectiveness of Malaise traps for collection of wasps (Hymenoptera: Aculeata). Pakistan Journal of Zoology 32(1):45-47.

Sudheendrakumar, V. V., Binoy, C. F. and Narendran, T. C., 1989, The Macro hymenopteran fauna of silent valley national park, Kerala, India. Bangladesh J. Forest Sci., 28(1): 38-46.

Suresh, P. V., Sudheendrakumar, V. V., Binoy, C. F. and Narendran, T. C., 1999, The macro hymenopteran fauna of Parambikulum wildlife sanctuary. Zoos' print., 24(4): 1-2.

Tilman D and J A Downing. 1994. Biodiversity and stability in grasslands. Nature, 367: 363-365.

Turner, R. E., 1912, Notes on fossorial Hymenoptera. - X. On new species from the Oriental and Ethiopian Regions. The Annals and Magazine of Natural History, 10(8): 361-377.

Unruh, T. R. and Messing, R,H. 1993, Intraspecific biodiversity in Hymenoptera, implications for conservation and biological control. In: LaSalle J, Gauld ID, editors. Hymenoptera and biodiversity. Wallingford (UK): CAB International and The Natural History Museum, 27-52 p.

Zar, J. H., 1996, Biostatistical Analysis. Prentice-Hall, 663 p.

\section{How to cite this article:}

Soumya Patil and Jemla Naik, D. 2020. Sphecid Wasp`s Diversity and Distribution Study of Bengaluru, Karnataka. Int.J.Curr.Microbiol.App.Sci. 9(08): 832-839. doi: https://doi.org/10.20546/ijcmas.2020.908.089 